\title{
Characterization of the Rheological, Textural, and Sensory Properties of Samples of Commercial US Cream Cheese with Different Fat Contents
}

\author{
M. Brighenti, ${ }^{*}$ S. Govindasamy-Lucey, † K. Lim, † K. Nelson, † and J. A. Lucey* ${ }^{\star 1}$ \\ *Department of Food Science, University of Wisconsin-Madison, Madison 53706-1565 \\ †Wisconsin Center for Dairy Research, Madison 53706-1565
}

\begin{abstract}
In this study, 18 commercial samples of cream cheeses from the United States, including full-fat, Neufchatel or one-third less fat, and fat-free cheeses were analyzed for their rheological, textural, and sensory properties. Dynamic rheological properties were measured by smallamplitude oscillatory rheology during heating from 5 to $80^{\circ} \mathrm{C}$ and cooling from 80 to $5^{\circ} \mathrm{C}$. The parameters measured were storage modulus $\left(\mathrm{G}^{\prime}\right)$ and loss tangent (LT). Hardness of cream cheeses was determined by penetration and spreadability tests with a texture analyzer. Quantitative descriptive sensory analysis was performed by a trained panel to determine textural properties including firmness, stickiness, cohesiveness of mass, gumminess, difficulty to dissolve, particle size, and difficulty to spread. Principal component analysis of sensory and instrumental parameters was performed to identify relationships between these different parameters and to group samples with similar characteristics. A standard recipe for preparation of cheesecakes was used to test the influence of type of cream cheese on cake properties. Hardness of cheesecakes was also determined by penetration. Most full-fat cream cheeses showed significantly greater $G^{\prime}$ values than the Neufchatel or fat-free cheeses at temperatures below $25^{\circ} \mathrm{C}$ during the heating cycle. For the cheeses containing fat (full fat and Neufchatel), G' values steeply decreased during heating up to $40^{\circ} \mathrm{C}$; the decrease was greater for fullfat cream cheese compared with Neufchatel cheeses. In full-fat cream cheese, one maximum in the LT profile was observed during heating at temperatures below $40^{\circ} \mathrm{C}$. In Neufchatel cheeses, a smaller maximum in LT was observed at temperatures below $40^{\circ} \mathrm{C}$, whereas fatfree cream cheeses showed no noticeable maximum LT in this temperature region. Most full-fat cream cheeses had greater values of hardness as determined by penetration or spreadability compared with Neufchatel or fat-free cheeses. Sensory analysis indicated that full-fat
\end{abstract}

Received May 2, 2008.

Accepted July 30, 2008.

${ }^{1}$ Corresponding author: jalucey@facstaff.wisc.edu cream cheeses were firmer, more cohesive, more difficult to dissolve and spread, and less sticky than Neufchatel or fat-free cheeses. The high hardness of full-fat cream cheese is presumably due to its greater fat content because after homogenization of the cream cheese mix, fat globules are partly covered with casein and participate in the aggregation of casein particles, reinforcing the structure of this product. These results indicate that there are significant differences in the textural properties of cream cheese made with different fat contents.

Key words: cream cheese, texture, sensory, rheology

\section{INTRODUCTION}

Production of cream and Neufchatel cheeses in the United States has tripled in the last 3 decades (IDFA, 2007). A reason for its increased popularity is the growing importance of the food ingredient sector (SchulzCollins and Senge, 2004) because cream cheese is mainly used in dips, as a base in flavored spreads, as a spread on bagels, and in desserts such as cheesecake (Fox et al., 2000). With the growing use of cream cheese as an ingredient, greater knowledge of its response to mixing, shearing, heating, and subsequent cooling is required to better control its functionality. However, there is limited information on the texture and rheology of cream cheese and on its behavior at high temperatures such as those used during baking.

Cream and Neufchatel cheese are typically manufactured from standardized (to a fat content of 8 to $14 \%$ for cream cheese and $\sim 5 \%$ for Neufchatel cheese), homogenized, and pasteurized milk or cream (Schulz-Collins and Senge, 2004). In commercial practice, the cheese milk is usually fortified and the total solids content can be greater than $20 \%$. The milk is then inoculated with a mesophilic starter culture and incubated until $\mathrm{pH}$ values of $\sim 4.5$ to 4.8 are reached (Fox et al., 2000). The gel is agitated and heat treated to facilitate some syneresis and reduce its viscosity (Lucey, 2002). Whey is then separated from the curd to obtain the desired moisture content using a centrifugal curd separator or ultrafiltration. The concentrated curd receives further treatments such as mixing, homogenization, and addi- 
tion of ingredients (e.g., salt and hydrocolloids; Guinee et al., 1993).

There is little information published on the processes used to make fat-free cream cheese. The process described by Crane (1992) for fat-free cream cheese indicates that these cheeses are manufactured using ingredients and processing steps different from those used in the manufacture of full-fat and Neufchatel cheeses, in one example of fat-free cream cheese. A concentrated skim milk (nonfat solids content of $\sim 25 \%$ ) is fermented to obtain a $\mathrm{pH}$ value between 5 and 4.8 , emulsifier salts (e.g., sodium citrate), bulking agents (e.g., buttermilk solids or corn syrup solids), and stabilizers (e.g., xanthan gum, carrageenan) are added to try to obtain a texture similar to fat-containing cream cheeses (Crane, 1992).

Many processing factors affect the structure and, therefore, the texture and rheology of cream cheese (Guinee et al., 1993). An increase in the levels of total solids (Becker and Puhan, 1989; Tamime and Robinson, 1999), gel-forming protein (Schulz-Collins and Senge, 2004), and fat (Martens, 1972; Becker and Puhan, 1989; Lucey et al., 1998) results in acid-induced casein gels with increased firmness. Almena-Aliste and Kindstedt (2005) reported that an increase in $\mathrm{pH}$ values from $\sim 4.7$ to 5.2 in full-fat and Neufchatel cream cheeses resulted in softer products. The greater firmness of cheeses at $\mathrm{pH} \sim 4.7$ could be due to the proximity of the isoelectric point of casein, which is around $\mathrm{pH} 4.6$ (Guinee et al., 1993). Homogenization pressure of the original cream cheese mix, and incubation temperature (Phadungath, 2003), addition of rennet (Schulz-Collins and Senge, 2004), addition of different types of stabilizers, homogenization pressure of the curd (Sanchez et al., 1994a; Wendin et al., 2000), and cooling rate (Sanchez et al., 1994b) all affect the textural and rheological properties of cream cheese. As a result, cream cheese samples with very different textural, rheological, and sensory attributes can be obtained.

There is limited information available on the dynamic rheological properties of cream cheese especially during heating and cooling, although these are important attributes when cream cheese is used in baked products such as cheesecake. This study aimed to characterize the rheological and textural properties of commercial cream cheeses with different fat levels and from different commercial brands. By comparing cheeses with different fat levels we will be able to identify the role(s) that fat plays in the textural properties of cream cheese. Another goal was to describe various textural, sensory, and rheological methods that should be applied for the evaluation of cream cheese. This study will provide a useful baseline of these properties for researchers interested in the study of cream cheese. The unique texture of cream cheese required the development of a lexicon for its sensory texture analysis. A descriptive language that described the different aspects of cream cheese texture was developed. Finally, relationships between sensory and instrumental (textural and rheological) parameters were determined by Pearson correlation coefficients and principal component analysis (PCA).

\section{MATERIALS AND METHODS}

\section{Cream Cheese Samples}

Eighteen commercial cream cheeses containing different fat levels from 8 different major US brands were purchased at local grocery stores in the Madison, Wisconsin, area. Samples included 8 full-fat cream cheeses, 8 Neufchatel cheeses, and 2 fat-free cream cheeses. We ensured that the cream cheeses purchased were not too close to their expiration date; that is, cheeses were purchased at least 1 mo before their expiration date. For each individual sample, only packages with the same expiration date were chosen, as this indicated that they were manufactured on the same day and would minimize some variability.

\section{Compositional Analyzes}

Cream cheeses were analyzed for moisture (IDF, 1982), fat (Marshall, 1992), and total protein (IDF, 1986). The $\mathrm{pH}$ values were determined by insertion of a $\mathrm{pH}$ probe ( $\mathrm{pH}$ meter $420 \mathrm{~A}$, Orion Research, Beverley, MA) into the cheeses.

\section{Rheological Measurements}

The rheological properties of cream cheeses were determined by dynamic small-amplitude oscillatory rheology. A controlled-stress rheometer (Paar Physica UDS 200, Physica Messtechnik, Stuttgart, Germany) was used with a $25-\mathrm{mm}$ serrated parallel plate. Samples were prepared using a cork borer with an internal diameter of $25 \mathrm{~mm}$ placed on a manually operated drill stand (used to make straight, parallel-sided samples). From the cork borer, samples were extruded as a cylinder using a plunger and cut in slices with a thickness of 2 to $3 \mathrm{~mm}$ and a diameter of $25 \mathrm{~mm}$ using a cheese slicer. Samples were heated from 5 to $80^{\circ} \mathrm{C}$ and cooled immediately from 80 to $5^{\circ} \mathrm{C}$ at a rate of $1^{\circ} \mathrm{C} / \mathrm{min}$, and then held at $5^{\circ} \mathrm{C}$ for $30 \mathrm{~min}$. These heating and cooling cycles were performed to observe the behavior of cream cheeses when subjected to high temperatures (because cream cheese is used in baked cheesecakes) and then cooled. A frequency of $0.1 \mathrm{~Hz}$ and a strain of $0.05 \%$ were used (strain sweep tests indicated that this was within 
Table 1. Ingredients and formula used to prepare cream cheesecakes

\begin{tabular}{lc}
\hline Ingredient & $\begin{array}{c}\text { Quantity } \\
(\% \text { wt } / \text { wt })\end{array}$ \\
\hline Cream cheese & 59.5 \\
Sugar & 17.0 \\
Whole eggs & 13.0 \\
Sour cream & 9.5 \\
Bread flour & 0.7 \\
Vanilla & 0.3 \\
Total & 100 \\
\hline
\end{tabular}

the linear viscoelastic region; results not shown). The parameters measured were elastic or storage modulus $\left(\mathbf{G}^{\prime}\right)$ and loss tangent $(\mathbf{L T})$, which is the ratio of loss modulus $\left(\mathbf{G}^{\prime \prime}\right)$ to storage modulus.

\section{Texture Tests}

Penetration and spreadability tests were performed using a TA.XT2 Texture Analyzer (Texture Technologies Corp., Scarsdale, NY). A 5-kg load cell was used for the penetration test, whereas a $20-\mathrm{kg}$ load cell was used for the spreadability test. Samples were analyzed at $5{ }^{\circ} \mathrm{C}$ to minimize differences in the solid fat contents.

Constant speed penetration tests were performed directly on brick-like packages $(12 \times 6.8 \times 3 \mathrm{~cm})$ of cream cheese pouches. A $45^{\circ}$ conical stainless steel probe (TA-15) was introduced $15 \mathrm{~mm}$ into the samples at a speed of $1 \mathrm{~mm} / \mathrm{s}$. The maximum force was described as penetration hardness $(\mathbf{H p})$; the maximum force was the point at which the probe was at its maximum penetration depth.

For spreadability tests, a set of matched male and female $45^{\circ}$ Perspex cones were used (TTC Spreadability Fixture, Texture Technologies Corp.; Swenson et al., 2000). The cream cheese sample was placed into the female cone and pressed down to eliminate air pockets. Excess sample was removed with a knife to leave a flat test surface. Samples were left in a refrigerator at $\sim 5^{\circ} \mathrm{C}$ for $24 \mathrm{~h}$ to allow the structure to recover after the filling of the female cone. For the test, the female cone containing the sample was aligned with the male cone. The male cone penetrated into the sample until it reached a depth of $2 \mathrm{~mm}$ above the sample holder (the female cone). The maximum force, the point at which the probe was at its maximum penetration depth was determined and was described as spreadability hardness (Hs). The areas under the curves were also determined and they represented the amount of work required to perform the shearing process; that is, to spread the samples along the surfaces of the female cone.

A penetration test was also performed on cheesecakes. One cake was baked for each different sample using a recipe from the American Institute of Baking (Abboud, 1998). Table 1 gives the amounts of the various ingredients included in this cheesecake recipe, and the recipe used to prepare the cheesecakes is given in Table 2. A $45^{\circ}$ conical stainless steel probe (TA-15) was used to penetrate a depth of $10 \mathrm{~mm}$ into the cake samples at a speed of $1 \mathrm{~mm} / \mathrm{s}$. Samples were always tested 3 $\mathrm{cm}$ from the edge of the cake to avoid differences in hardness due to a particular position in the cheesecake. The maximum force observed during penetration; that is, the force at a penetration depth of $10 \mathrm{~mm}$, was considered as the cheesecake hardness $(\mathbf{H c})$.

\section{Sensory Properties}

A trained sensory panel consisting of at least 8 panelists (usually 8 to 12 ) used sensory spectrum descriptive analysis (Meilgaard et al., 1999) to evaluate the textural properties of cream cheese. The panel received 14 sessions of training that lasted approximately 20 $\mathrm{h}$ in total. During these sessions the panelists defined texture terms and were trained about the appropriate techniques for evaluating the samples and in the use of reference scales. Panelists determined 7 key textural attributes that were used to describe the texture profile of cream cheeses. These descriptors were firmness, stickiness, gumminess, cohesiveness of mass, difficulty to dissolve, particle size, and difficulty to spread. The

Table 2. Recipe used for the preparation of cream cheesecakes (derived from American Institute of Baking)

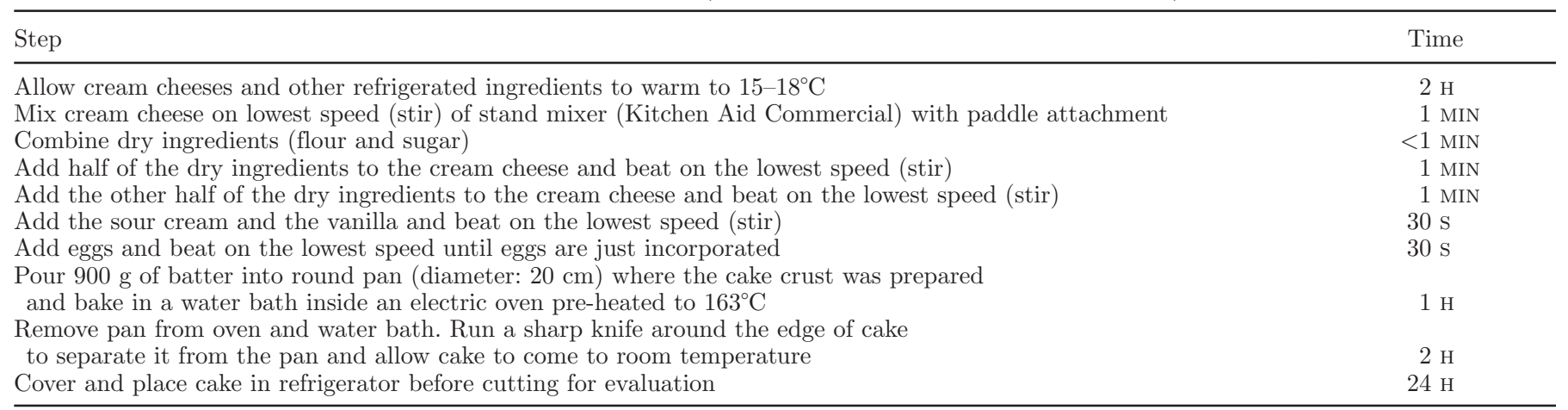


panel also defined how each of these descriptors should be assessed. The numerical intensity scale for each attribute ranged from 0 to 15 and contained at least 4 reference points, with higher numbers indicating greater intensities (Table 3).

Table 3 shows the descriptors, their definitions, and the techniques used for their evaluation as well as the reference standards determined by the consensus of the panel. About $50 \mathrm{~mL}$ of product was placed in $74-\mathrm{mL}$ plastic cups sealed with plastic lids. Samples were stored at $\sim 4^{\circ} \mathrm{C}$ for at least $24 \mathrm{~h}$, and panelists immediately tested them after removal from the refrigerator. Panelists were required to take approximately one-quarter of a spoon $(\sim 3 \mathrm{~g})$ of product into their mouths when they evaluated each attribute except for spreadability, where they took approximately half a spoon $(\sim 6 \mathrm{~g})$ of product, placed it on cocktail bread, and spread it using a knife. Ambient-temperature water was provided to panelists to wash their mouths between samples.

During each evaluation session, a maximum of 5 to 6 samples were evaluated. Each sample was identified by a random 3-digit numeric code. In addition to the samples, panelists were provided with references (Table $3)$. Each sample was evaluated in triplicate on 3 consecutive days. Either the spreadable-type cream cheese or the full-fat cream cheese that were used as references were included as blind samples in each session to determine panelist consistency over time.

\section{Statistical Analyses}

Data were analyzed using SAS software (version 8.02, SAS Institute, 2003). Effect of fat level on the rheological, textural, and sensory properties of cream cheeses was evaluated using PROC MIXED for repeated measurements in SAS. Effect of brand on those cheeses belonging to the same category (i.e., similar fat level) was also evaluated. When treatment effects were significant $(P \leq 0.05)$, the differences between means were analyzed using Tukey's method for multiple comparisons of means. Pearson correlation coefficients were estimated between the various responses (rheological, textural, and sensory parameters) using the Statgraphics software (version 5.1 plus, Manugistics, Rockville, $\mathrm{MD})$. This software was also used to perform PCA of the sensory attributes and of the sensory attributes together with the instrumental parameters.

\section{RESULTS}

\section{Compositional Analysis}

There was variability in the gross composition of cheeses belonging to the same category (Table 4). However, most full-fat cream cheeses complied with the standard of identity of full-fat cream cheese, which requires a maximum moisture content of $55 \%$ and a minimum fat content of $33 \%$ (Code of Federal Regulations, 2006b). One sample had a moisture content of $56.4 \%$, slightly above the maximum permitted level. The protein levels ranged from 5.52 to $7.70 \%$ and the $\mathrm{pH}$ values were between 4.62 and 5.01. In the case of Neufchatel cheeses, the variability between brands in their moisture (from 61.24 to $65.59 \%$ ) and fat contents (from 20.69 to $25.17 \%$ ) was even greater than what was observed for the full-fat cream cheeses. All of the samples tested complied with the standard of identity for Neufchatel cheese, which states that cheeses should have a maximum moisture content of $65 \%$ and that their fat content should be not less than $20 \%$ and not more than 33\% (Code of Federal Regulations, 2006b). Protein contents of the Neufchatel cheeses ranged from 7.24 to $8.84 \%$ and were, on average, greater than the protein contents of full-fat cream cheeses. The $\mathrm{pH}$ values of Neufchatel cheeses were similar to those of full-fat cream cheeses, with values between 4.62 and 5.16. There is no standard of identity for fat-free cream cheeses; however, these products have to comply with the regulation for labeling fat-free products, which requires that the fat content should be less than $0.5 \mathrm{~g}$ per serving (Code of Federal Regulations, 2006a), which is $28 \mathrm{~g}$ of cheese. Fat contents per serving were calculated for the 2 fat-free cream cheeses from brands A and B and the values obtained were 0.3 and $0.5 \mathrm{~g}$, respectively. The moisture content, protein content, and $\mathrm{pH}$ values of fat-free cream cheeses were approximately $70 \%, 15 \%$, and 5.3, respectively. These values were considerably greater than those found in full-fat and Neufchatel cheeses.

\section{Rheological Measurements}

The $G^{\prime}$ values of various cream cheese samples during heating and cooling are shown in Figure 1. The $\mathrm{G}^{\prime}$ values of all cream cheeses decreased as cheese temperature increased. Storage modulus values at $8^{\circ} \mathrm{C}\left(\mathbf{G}^{\prime}{ }_{8 \mathrm{C}}\right)$ were used as an indication of the number and strength of interactions present at low temperatures. There were significant $(P<0.0001)$ differences in $\mathrm{G}^{\prime}{ }_{8 \mathrm{C}}$ between cheeses with different fat levels (Table 5). Full-fat cream cheeses had significantly greater $\mathrm{G}_{8 \mathrm{C}}$ than Neufchatel and fat-free cream cheeses, and Neufchatel had significantly greater values than fat-free cream cheeses. When comparing cheeses from the same category (i.e., similar fat level), brand was a significant factor for full-fat and Neufchatel cheeses $(P<0.0001)$ as well as for fat-free cheeses $(P<0.001)$ in $\mathrm{G}_{8 \mathrm{C}}^{\prime}$ (Table 6$)$.

At temperatures above $25^{\circ} \mathrm{C}$, no consistent differences were observed in the $G^{\prime}$ values of full-fat and Neufcha- 
Table 3. Definitions, techniques, and references used in the spectrum sensory analysis

\begin{tabular}{|c|c|c|c|}
\hline Descriptor & Definition & Technique & Reference \\
\hline Firmness & $\begin{array}{l}\text { Force required to compress sample between } \\
\text { tongue and palate during compression }\end{array}$ & $\begin{array}{l}\text { Place sample on tongue, compress it against } \\
\text { the palate once at a steady rate }\end{array}$ & $\begin{array}{l}0=\text { Cool Whip }^{1}(\text { soft }) \\
5=\text { Spreadable cream } \text { cheese }^{2} \\
9=\text { Full-fat cream cheese }^{3} \\
15=\text { Butter }^{4}(\text { firm })\end{array}$ \\
\hline Stickiness & Amount of sample that adheres to palate & $\begin{array}{l}\text { Place sample on tongue, lift it up softly against } \\
\text { palate without squeezing the sample }\end{array}$ & $\begin{array}{l}0=\text { Cool Whip (not gummy) } \\
7=\text { Full-fat cream cheese } \\
11=\text { Spreadable cream cheese } \\
13.5=\text { Peanut butter }{ }^{5} \text { (sticky) }\end{array}$ \\
\hline Gumminess & Springy and rubbery characters of the sample & $\begin{array}{l}\text { Compress sample between tongue and } \\
\text { palate, then move tongue against palate }\end{array}$ & $\begin{array}{l}0=\text { Cool Whip (not sticky) } \\
4=\text { Spreadable cream cheese } \\
6=\text { Full-fat cream cheese } \\
8=\text { Neufchatel cheese }^{6} \text { (gummy) }\end{array}$ \\
\hline $\begin{array}{l}\text { Cohesiveness } \\
\text { of mass }\end{array}$ & Degree to which sample holds together in a mass & $\begin{array}{l}\text { Place sample in mouth; compress it with } \\
\text { tongue against palate at least } 5 \text { times }\end{array}$ & $\begin{array}{l}0=\text { Cool Whip (not cohesive) } \\
6=\text { Marshmallow cream } \\
8=\text { Spreadable cream cheese } \\
10.5=\text { Full-fat cream cheese } \\
14.5=\text { Peanut butter (cohesive) }\end{array}$ \\
\hline $\begin{array}{l}\text { Difficulty to } \\
\text { dissolve }\end{array}$ & $\begin{array}{l}\text { Rate and degree that the sample breaks } \\
\text { down due to salivary, mechanical action }\end{array}$ & $\begin{array}{l}\text { Break down sample by manipulating } \\
\text { between tongue and palate }\end{array}$ & $\begin{array}{l}0.5=\text { Cool Whip (easy) } \\
5=\text { Marshmallow cream } \\
8=\text { Spreadable cream cheese } \\
10=\text { Full-fat cream cheese } \\
12=\text { Peanut butter (difficult) }\end{array}$ \\
\hline Particle size & $\begin{array}{l}\text { Size of the residual particles in the mass } \\
\text { after thorough manipulation }\end{array}$ & Place sample in mouth and manipulate it thoroughly & $\begin{array}{l}0=\text { Vanilla pudding }^{8}(\text { small }) \\
1.5=\text { Full-fat cream cheese } \\
10=\text { Ricotta cheese }^{9} \\
14=\text { Apple sauce }^{10}(\mathrm{big})\end{array}$ \\
\hline \multicolumn{2}{|c|}{$\begin{array}{c}\text { Difficulty to spreadInitial stage force (time and effort) needed } \\
\text { to spread the sample with a knife }\end{array}$} & $\begin{array}{l}\text { Cover } 1 / 4 \text { of flat knife surface with sample and } \\
\text { spread it to a thin even layer on a cocktail bread }{ }^{11}\end{array}$ & $\begin{array}{l}0=\text { Cool Whip (easy) } \\
3=\text { Peanut butter } \\
6=\text { Spreadable cream cheese } \\
8=\text { Full fat cream cheese } \\
14=\text { Butter (difficult) }\end{array}$ \\
\hline
\end{tabular}

을 ${ }^{1}$ Extra creamy Cool Whip; 8 oz. (Kraft Foods; Tarrytown, NY).

产 2 Philadelphia regular cream cheese spread; 16 oz. tub (Kraft Foods; Glenview, IL).

$\stackrel{3}{3}$ Philadelphia original cream cheese; 8 oz. (Kraft Foods; Northfield, IL).

I Land O'Lakes unsalted butter; $1 \mathrm{lb}$. (Land O'Lakes, Inc.; Arden Hills, MN).

旁. $\quad{ }^{5}$ Skippy creamy peanut butter; 18 oz. (Unilever, Englewood Cliffs, NJ).

응. ${ }^{6}$ Crystal Farms Neufchatel cream cheese; 8 oz. (Crystal Farms, Lake Mills, WI).

官 $\quad{ }^{7}$ Jet-puffed Marshmallow Creme; 7 oz. (Kraft Foods; Northfield, IL).

8 Jell-O vanilla pudding; 24 oz. (Kraft Foods; Northfield, IL).

$\bigcirc \quad{ }^{9}$ Frigo whole milk ricotta cheese; 15 oz. (Saputo, Lincolnshire, IL).

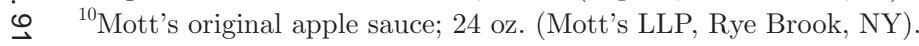

z ${ }^{11}$ Rubschlager cocktail pumpernickel bread; 1 lb. (Rubschlager Baking Corp., Chicago, IL). 
Table 4. Composition of full-fat, Neufchatel, and fat-free cream cheeses (means and SD)

\begin{tabular}{|c|c|c|c|c|c|c|}
\hline Brand & Type & Moisture, \% & Fat, $\%$ & Protein, \% & $\mathrm{pH}$ & Stabilizers $^{1}$ \\
\hline \multirow{2}{*}{ A } & Neufchatel & $61.24(0.35)$ & $25.17(0.35)$ & $8.72(0.48)$ & $4.84(0.03)$ & $\mathrm{X}$ and/or $\mathrm{LB}$ and/or $\mathrm{G}$ \\
\hline & Fat-free & $70.25(0.03)$ & $0.94(0.13)$ & $16.01(0.48)$ & $5.25(0.01)$ & $\mathrm{X}$ and/or LB and/or G and/or C \\
\hline \multirow{2}{*}{$\mathrm{B}$} & Neufchatel & $63.88(0.41)$ & $23.84(0.09)$ & $8.43(0.04)$ & $4.67(0.01)$ & $\mathrm{X}$ and/or LB and/or $\mathrm{G}$ \\
\hline & Fat-free & $71.57(0.02)$ & $1.74(0.04)$ & $15.20(0.20)$ & $5.41(0.01)$ & $\mathrm{X}, \mathrm{LB}$, and $\mathrm{C}$ \\
\hline $\mathrm{C}$ & Full fat & $53.31(0.84)$ & $34.80(0.26)$ & $7.01(0.15)$ & $4.73(0.01)$ & $\mathrm{LB}$ \\
\hline $\mathrm{D}$ & Neufchatel & $64.21(0.00)$ & $24.80(0.11)$ & $8.02(0.10)$ & $4.93(0.04)$ & $\mathrm{X}$ and/or LB and/or G \\
\hline \multirow[t]{2}{*}{$\mathrm{E}$} & Full fat & $56.41(1.23)$ & $32.91(0.46)$ & $5.52(0.19)$ & $4.62(0.01)$ & $\mathrm{X}$ and/or $\mathrm{LB}$ and/or $\mathrm{G}$ \\
\hline & Neufchatel & $63.57(0.30)$ & $21.77(0.61)$ & $8.38(0.01)$ & $4.82(0.00)$ & $\mathrm{X}$ and/or $\mathrm{LB}$ and/or $\mathrm{G}$ \\
\hline \multirow[t]{2}{*}{$\mathrm{F}$} & Full fat & $54.44(0.07)$ & $34.69(0.67)$ & $7.70(0.25)$ & $4.64(0.01)$ & $\mathrm{X}$ and/or LB and/or G \\
\hline & Neufchatel & $65.18(0.46)$ & $23.05(0.13)$ & $8.11(0.00)$ & $4.62(0.00)$ & $\mathrm{X}$ and/or LB and/or G \\
\hline \multirow[t]{2}{*}{ G } & Full fat & $54.65(0.13)$ & $34.96(0.04)$ & $5.67(0.21)$ & $5.01(0.01)$ & $\mathrm{X}$ and/or LB and/or $\mathrm{G}$ \\
\hline & Neufchatel & $61.99(0.20)$ & $24.84(0.36)$ & $8.84(0.53)$ & $5.16(0.02)$ & $\mathrm{X}$ and/or $\mathrm{LB}$ and/or $\mathrm{G}$ \\
\hline
\end{tabular}

${ }^{1} \mathrm{X}=$ xanthan gum; $\mathrm{LB}=$ locust bean gum; $\mathrm{G}=$ guar gum; $\mathrm{C}=$ carrageenan.

tel cheeses; some full-fat samples had greater $\mathrm{G}^{\prime}$ values than Neufchatel cheeses, whereas the opposite trend was observed for other brands. In the case of fat-free cream cheeses, their $G^{\prime}$ values were greater than the $G^{\prime}$ values of the full-fat and Neufchatel cheeses from their brands at temperatures between 35 and $75^{\circ} \mathrm{C}$. The $\mathrm{G}^{\prime}$ profiles could be divided into 2 regions for full-fat and Neufchatel cream cheeses. In the low temperature region $\left(5\right.$ to $\left.40^{\circ} \mathrm{C}\right)$ there was a greater rate of decrease in $\mathrm{G}^{\prime}$ compared with the high temperature region $\left(>40^{\circ} \mathrm{C}\right)$. In the second region $\left(>40^{\circ} \mathrm{C}\right)$, the $\mathrm{G}^{\prime}$ values decreased slowly compared with the low temperature region. In the case of fat-free cream cheeses (Figure 1, panels a and b) no distinctly different temperature regions were observed, only a steady decrease in the $\mathrm{G}^{\prime}$ values with an increase in temperature.

During cooling from 80 to $5^{\circ} \mathrm{C}$, the $\mathrm{G}^{\prime}$ values of all cream cheeses increased with a greater rate of increase at temperatures $<30^{\circ} \mathrm{C}$ (Figure 1 , panels a to $\mathrm{h}$ ). The greatest $\mathrm{G}^{\prime}$ values were observed at $5^{\circ} \mathrm{C}$. However, for most full-fat and Neufchatel cheeses, the $\mathrm{G}^{\prime}$ values at $5^{\circ} \mathrm{C}$ after the cooling cycle were significantly lower than the $\mathrm{G}^{\prime}$ values at $5^{\circ} \mathrm{C}$ before heating the samples. Fatfree cheeses had a similar rate of increase in $\mathrm{G}^{\prime}$ during the entire cooling range from 80 to $5^{\circ} \mathrm{C}$. Little change in the $\mathrm{G}^{\prime}$ values was observed during further holding of all cream cheeses at $5^{\circ} \mathrm{C}$ for $30 \mathrm{~min}$ (results not shown).

Loss tangent values of cream cheeses when heated from 5 to $80^{\circ} \mathrm{C}$ and subsequently cooled from 80 to $5^{\circ} \mathrm{C}$ are shown in Figure 2. During the heating cycle, full-fat and Neufchatel cream cheeses exhibited an LT peak at around 20 to $30^{\circ} \mathrm{C}$, whereas fat-free cream cheeses did not exhibit any LT peak in the range from 5 to $40^{\circ} \mathrm{C}$. Full-fat cream cheeses had significantly $(P<0.0001)$ greater maximum LT values (i.e., the peak value at temperatures $<40^{\circ} \mathrm{C}$ ) than Neufchatel cheeses (Figure 2 , panels a to h; Table 5 ). When cheeses with similar fat levels were compared, brand was a significant factor for full-fat $(P<0.01)$ and Neufchatel cheeses $(P<0.05$; Table 6). In some Neufchatel cheeses (brands C, D, and $\mathrm{H})$ a second, smaller peak was observed at $\sim 60^{\circ} \mathrm{C}$. The LT values of fat-free cream cheese from brands $\mathrm{A}$ and B increased slightly at $\sim 55$ and $45^{\circ} \mathrm{C}$, respectively (Figure 2, panels a and b). During the cooling cycle, most full-fat and Neufchatel cheeses showed a small peak or shoulder at temperatures around $45^{\circ} \mathrm{C}$ (Figure 2). In all cheese samples, the greatest LT values were found around $5{ }^{\circ} \mathrm{C}$. In the case of fat-free cream cheeses during cooling, a slight increase was observed around $30^{\circ} \mathrm{C}$ (Figure 2, panels a and b). The values for the LT peaks found in all types of cream cheeses during either the heating or cooling cycles were much smaller compared with the values $(>1)$ for the LT peaks observed during the heating and cooling of most rennet-coagulated cheeses such as Cheddar and Mozzarella (Lucey et al., 2003).

When the $\mathrm{G}^{\prime}$ and $\mathrm{LT}$ values obtained during the heating and cooling cycles for all cream cheese samples were compared, hysteresis was observed. This hysteresis was more pronounced in full-fat and Neufchatel cheeses than in the fat-free samples.

\section{Texture Analysis}

Fat level had a significant $(P<0.0001)$ effect on $\mathrm{Hp}$ of cheeses (Table 5). When cheeses from the same category were compared, type of brand had a significant effect on the values obtained for full-fat, Neufchatel, and fat-free cheeses $(P<0.0001$; Table 6). Full-fat cream cheeses had significantly greater $\mathrm{Hp}$ values than 


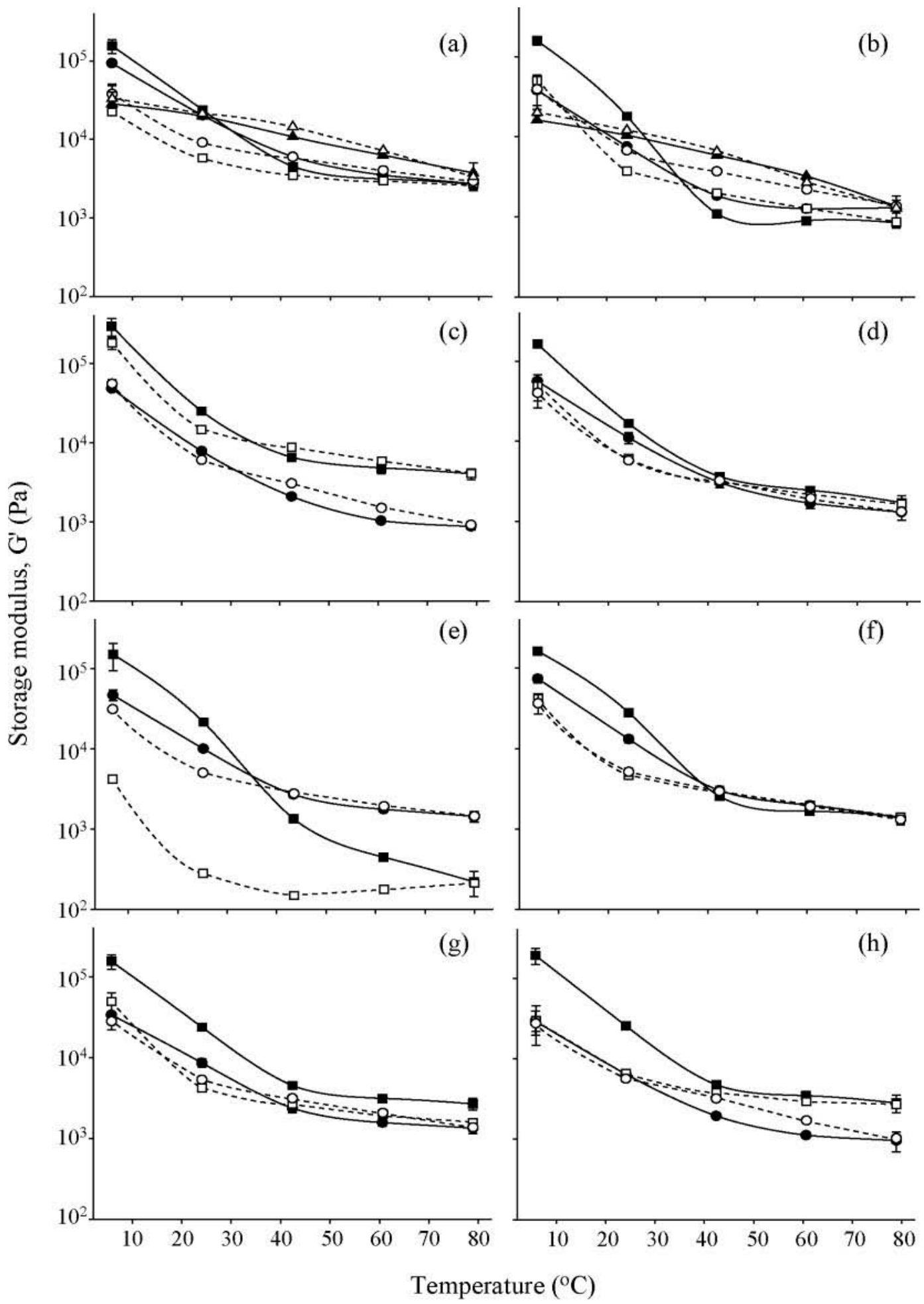

Figure 1. Storage modulus $\left(\mathrm{G}^{\prime}\right)$ values during the heating of full-fat $(-\mathbf{-}-)$, Neufchatel $(-\mathbf{-}-)$, and fat-free $(-\mathbf{\Delta}-)$ cream cheeses from brands A to H (panels a to h, respectively); and cooling of full-fat (--- $\square---$ ), Neufchatel (--- $\bigcirc---)$ and fat-free (--- $\Delta---)$ cream cheeses from brands A to $\mathrm{H}$ (panels a to h, respectively). Heating was from 5 to $80^{\circ} \mathrm{C}$ and cooling from 80 to $5^{\circ} \mathrm{C}$ at $1{ }^{\circ} \mathrm{C} / \mathrm{min}$. Solid lines represent heating and dashed lines represent cooling. Values are means of 3 replicates, and error bars represent standard deviations of the mean. 
Table 5. Mean squares and probabilities for rheological, textural, and sensory properties of cream cheeses

\begin{tabular}{|c|c|c|c|c|c|c|c|c|c|}
\hline \multirow[b]{2}{*}{ Source } & \multicolumn{9}{|c|}{ Property $^{2}$} \\
\hline & $\mathrm{G}_{8 \mathrm{C}}^{\prime}$ & LT & $\mathrm{Hp}$ & $\mathrm{Hs}$ & Firm & Stick & Coh & Diss & Spread \\
\hline Fat level & $69,178,670,465^{* * * *}$ & $0.0148^{* * * *}$ & $1,104,153^{* * * *}$ & $468,026,988^{* * * *}$ & $73^{* * * *}$ & $47^{* * * *}$ & $44^{* * * *}$ & $28^{* * * *}$ & $40^{* * * *}$ \\
\hline Error & $674,485,476$ & 0.0004 & 21,733 & $12,790,405$ & 2 & 2 & 1 & 1 & 0.8969 \\
\hline
\end{tabular}

${ }^{1}$ Data were analyzed for the effect of fat levels.

${ }^{2} \mathrm{G}_{8 \mathrm{C}}^{\prime}=$ storage modulus at $8^{\circ} \mathrm{C}$; LT $=$ maximum loss tangent; Hs $=$ hardness determined by spreadability test; Hp $=$ hardness determined by penetration test; Firm $=$ firmness determined by sensory evaluation; Stick = stickiness determined by sensory evaluation; Coh = cohesiveness determined by sensory evaluation; Diss $=$ difficulty to dissolve determined by sensory evaluation; Spread = difficulty to spread determined by sensory evaluation.

$* * * * P<0.0001$

Table 6. Mean squares and probabilities for rheological, textural, and sensory properties of cream cheeses categorized into different fat levels ${ }^{1}$

\begin{tabular}{|c|c|c|c|c|c|c|c|c|c|}
\hline \multirow[b]{2}{*}{ Source } & \multicolumn{9}{|c|}{ Property $^{2}$} \\
\hline & $\mathrm{G}_{8 \mathrm{C}}^{\prime}$ & $\mathrm{LT}$ & $\mathrm{Hp}$ & $\mathrm{Hs}$ & Firm & Stick & Coh & Diss & Spread \\
\hline \multicolumn{10}{|l|}{ Full fat } \\
\hline Type of brand & $2,778,779,147^{* * * *}$ & $0.0014^{* *}$ & $218,870^{* * * *}$ & $42,422,198^{* * * *}$ & $2^{* *}$ & $1^{* * *}$ & $1^{* * *}$ & $2^{\mathrm{NS}}$ & $2^{* * * *}$ \\
\hline Error & $180,274,017$ & $<0.001$ & 413 & 212,439 & 0.3652 & 0.1671 & 0.1368 & 0.9432 & 0.1430 \\
\hline \multicolumn{10}{|l|}{ Neufchatel } \\
\hline Type of brand & $1,027,127,750^{* * * *}$ & $0.0005^{*}$ & $127,987^{* * * *}$ & $74,268,766^{* * * *}$ & $9 * * * *$ & $13^{* * * *}$ & $6^{* * * *}$ & $4^{* * * *}$ & $4 * * * *$ \\
\hline Error & $74,260,866$ & 0.0001 & 937 & $1,579,377$ & 0.3644 & 0.1392 & 0.2314 & 0.2212 & 0.2334 \\
\hline \multicolumn{10}{|l|}{ Fat-free } \\
\hline Type of brand & $95,408,333^{* * *}$ & - & $38,966^{* * * *}$ & $49,230^{\mathrm{NS}}$ & $0.4320^{*}$ & $0.0523^{\mathrm{NS}}$ & $3^{* * *}$ & $1^{* * *}$ & $1^{* * *}$ \\
\hline Error & 257,222 & - & 79 & 17,696 & 0.0418 & 0.0928 & 0.0285 & 0.0178 & 0.0165 \\
\hline
\end{tabular}

${ }^{1}$ Data were analyzed for the effect of type of brand.

${ }^{2} \mathrm{G}_{8 \mathrm{C}}^{\prime}=$ storage modulus at $8^{\circ} \mathrm{C}$; LT $=$ maximum loss tangent; $\mathrm{Hs}=$ hardness determined by spreadability test; Hp = hardness determined by penetration test; Firm $=$ firmness determined by sensory evaluation; Stick = stickiness determined by sensory evaluation; Coh = cohesiveness determined by sensory evaluation; Diss $=$ difficulty to dissolve determined by sensory evaluation; Spread $=$ difficulty to spread determined by sensory evaluation.

${ }^{*} P<0.05 ;{ }^{* *} P<0.01 ;{ }^{* * *} P<0.001 ;{ }^{* * * *} P<0.0001{ }^{N S}=$ not significant. 
Neufchatel and fat-free cheeses (Figure 3). When comparing Neufchatel to fat-free cream cheeses we observed that the Neufchatel cream cheese from brand A had significantly $(P<0.0001)$ greater $H p$ values than the fat-free cheese from that same brand. However, when comparing the Neufchatel and fat-free cheese from brand B, the opposite result was obtained.

For instrumental spreadability, the Hs (i.e., maximum force) and work of shear gave similar trends. Fat level significantly $(P<0.0001)$ affected $H s$ values obtained for the different cream cheeses (Figure 4; Table 5). Type of brand was also significant for full fat and Neufchatel cheeses $(P<0.0001)$ but not for fatfree cheeses when we compared cheeses within a same category (i.e., similar fat level). Full-fat cream cheeses had significantly $(P<0.0001)$ greater Hs values than Neufchatel or fat-free cream cheeses. Neufchatel cheeses had significantly $(P<0.0001)$ greater $\mathrm{Hs}$ values than fat-free cream cheeses.

The Hc values of cheesecakes were determined by a penetration test (Figure 5). As only one cake was baked per treatment, we did not perform any statistical analyses. We observed a trend that most cakes made from full-fat cream cheeses had greater Hc values than cakes containing Neufchatel cheeses except for brand $\mathrm{E}$, in which the $\mathrm{Hc}$ values were similar. The Hc values of the cakes baked with the fat-free cream cheeses from brands $\mathrm{A}$ and $\mathrm{B}$ were lower than the cakes containing the full-fat and Neufchatel cheeses from the same type of brands.

\section{Sensory Analysis}

There were significant differences $(P<0.001)$ between the sensory attributes of cheeses with different fat levels (Table 5). Full-fat cream cheeses were firmer, less sticky, more cohesive, more difficult to dissolve, and more difficult to spread than Neufchatel and fatfree cream cheeses. Neufchatel cheeses were firmer, less sticky, more cohesive, more difficult to dissolve, and more difficult to spread than fat-free cream cheeses. When cheeses from the same category were compared, type of brand also had a significant effect on the values of firmness, cohesiveness, and difficulty to spread of full-fat, Neufchatel, and fat-free cheeses (Table 6). In the case of stickiness, type of brand had a significant effect on the values of full-fat and Neufchatel cheeses, but not on those of fat-free cheeses. For difficulty to dissolve, type of brand had a significant effect on the values of Neufchatel and fat-free cheeses.

Principal component analysis of the sensory results indicated that $93 \%$ of the total variation among the samples could be explained by 2 principal components (PC), PC1 and PC2 (Figure 6). The first PC explained
$77 \%$ of this variation and was positively driven by firmness, cohesiveness of mass, difficulty to spread, and difficulty to dissolve, whereas stickiness had a negative loading. Gumminess and particle size loaded positively on $\mathrm{PC} 2$, which accounted for $16 \%$ of the variation observed in the cream cheese samples. The biplot of PC1 and $\mathrm{PC} 2$ showed that the variables firmness, cohesiveness of mass, difficulty to dissolve, and difficulty to spread were grouped, indicating that they were correlated. Pearson correlation coefficients were estimated between the sensory attributes, and high positive linear correlations $(\mathrm{r}>0.94, P<0.0001)$ were found between firmness, cohesiveness of mass, difficulty to dissolve, and difficulty to spread. These sensory attributes were also highly negatively correlated to stickiness ( $\mathrm{r}>$ $-0.90, P<0.0001$ ). Principal component analysis of sensory results distinguished the samples into 3 different groups. The first group included samples that showed positive scores in PC1 (due to high values of firmness, difficulty to spread, cohesiveness of mass, difficulty to dissolve, and low values of stickiness). All full-fat cream cheeses fell into this category and 3 Neufchatel cheeses also belonged to this group. The full-fat sample from brand $G$ had characteristics similar to those cheeses from group 1 but had also high scores in PC2 (because of high gumminess). Cheeses in group 2 had negative scores in PC1 because of their low firmness/hardness and high stickiness values. This category included most Neufchatel cheeses and the fat-free cheese from brand B. Neufchatel cheese from brand $\mathrm{H}$ and fat-free cheese from brand A also exhibited high stickiness and low hardness values but also had greater particle size (group 3; Figure 6).

\section{Relationships Between Instrumental and Sensory Properties}

High positive correlations were observed between the $\mathrm{G}_{8 \mathrm{C}}^{\prime}, \mathrm{Hp}$ values, Hs values, and the sensory attributes firmness, cohesiveness of mass, difficulty to dissolve, and difficulty to spread (Table 7). Positive correlations were also observed between the instrumental properties and gumminess (as determined by sensory analysis). High negative correlations were found between several instrumental parameters $\left(\mathrm{G}_{8 \mathrm{C}}{ }^{\mathrm{C}}, \mathrm{Hp}\right.$, and $\left.\mathrm{Hs}\right)$ and stickiness.

Principal component analysis on both instrumental and sensory results is shown in Figure 7. Principal components 1 and 2 explained $87 \%$ of the variability found in the cream cheese samples. For PC1, which explained $76 \%$ of the variability observed, the sensory attributes firmness, cohesiveness of mass, difficulty to spread, and difficulty to dissolve loaded positively as did the instrumental parameters $\left(\mathrm{G}_{8 \mathrm{C}}^{\prime}, \mathrm{Hp}\right.$, and $\left.\mathrm{Hs}\right)$. The sensory 

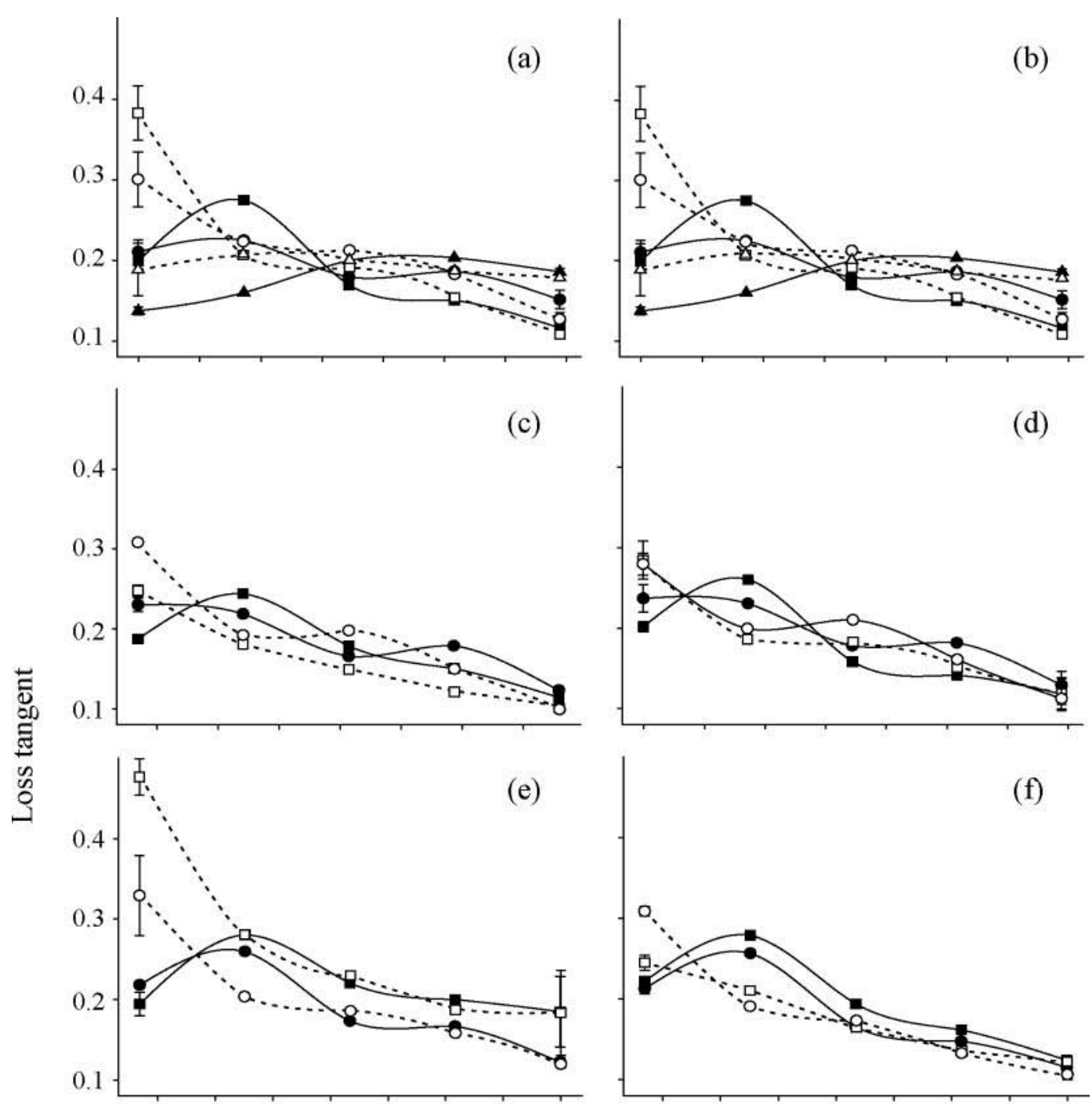

(b)
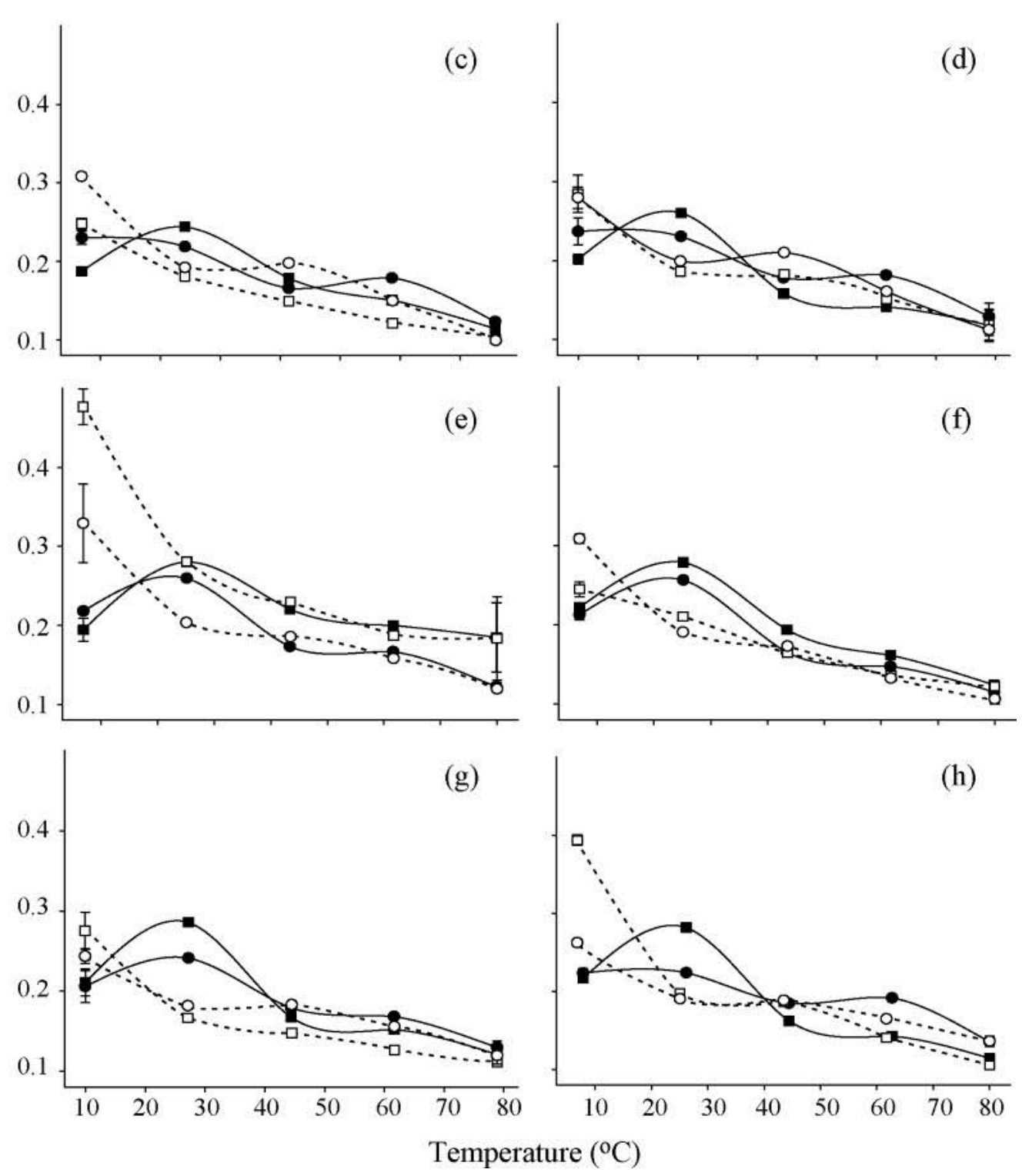

Figure 2. Loss tangent values during the heating of full-fat (- - - ), Neufchatel (- - - ), and fat-free $(-\mathbf{\Lambda}-)$ cream cheeses from brands A to $\mathrm{H}$ (panels a to h, respectively); and cooling of full-fat (--- $\square---)$, Neufchatel (---O---) and fat-free (--- $\Delta$---) cream cheeses from brands A to H (panels a to h, respectively). Heating was from 5 to $80^{\circ} \mathrm{C}$ and cooling from 80 to $5^{\circ} \mathrm{C}$ at $1^{\circ} \mathrm{C} / \mathrm{min}$. Solid lines represent heating and dashed lines represent cooling. Values are means of 3 replicates, and error bars represent standard deviations of the mean. 


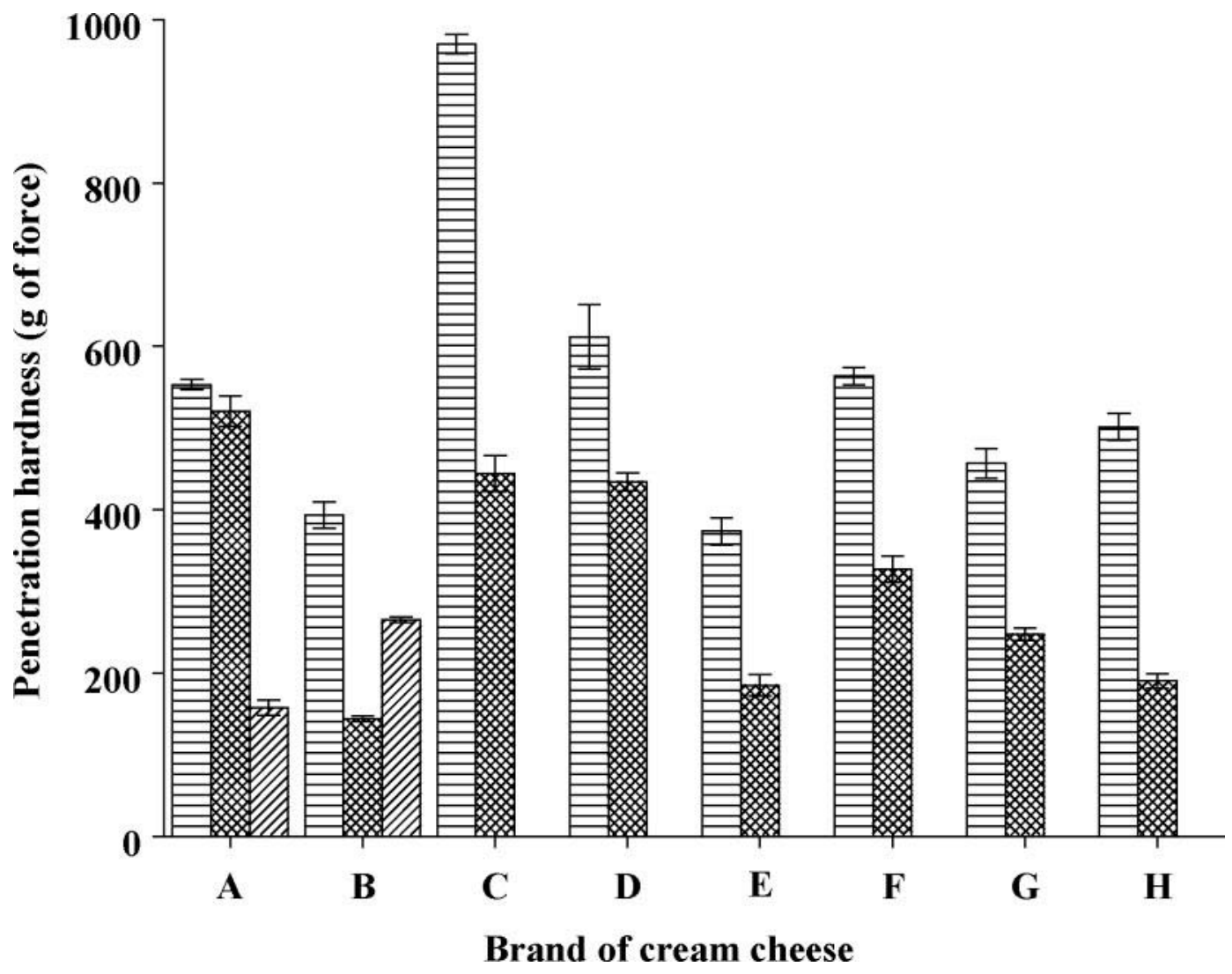

Figure 3. Hardness determined by penetration test of full-fat (horizontal hatch), Neufchatel (cross hatch), and fat-free (diagonal hatch) cream cheeses obtained from 8 different brands. Values are means of at least 3 replicates and error bars represent standard deviations of the mean.

attribute stickiness loaded negatively in PC1. Principal component 2 explained $11 \%$ of the variability and it was positively driven by the variables particle size and gumminess. Instrumental variables did not have high loading factors in $\mathrm{PC} 2$.

The position of the samples in the biplot of PC1 versus PC2 enabled the grouping of samples with similar characteristics. Three different groups were observed (Figure 7). Most full-fat cream cheeses belonged to group 1 and fell in the lower right quadrant except for full-fat cream cheese from brand $\mathrm{G}$, which was in the upper left quadrant because of high gumminess. Some Neufchatel cheeses belonged to group 1; they had positive PC1 values because of high scores in the attributes related to hardness and low stickiness. Other Neufchatel cheeses as well as the fat-free sample from brand B were included in group 2 and they had negative scores in PC1 (high stickiness and low hardness values). Group 3 contained the fat-free sample from brand A and Neufchatel cheese from brand H, which had high stickiness and low hardness scores but, at the same time, exhibited large particle size.

\section{DISCUSSION}

In this study, the rheological and textural properties of different US commercial cream cheeses were determined to better characterize the physicochemical properties of this product. Cream cheese is manufactured from homogenized milk and has a high fat content. Therefore, cream cheeses with different fat levels were chosen as it was likely that the amount of fat would have an effect on the texture of cream cheese. Significant differences were observed in the rheological, textural, and sensory properties of cream cheeses that have different fat levels. However, there was also some variability in the properties of cheeses belonging to the same category (similar fat contents; Table 6). One possible reason for the observed variability could be the differences in gross chemical composition (Table 4). Differences of between 2 and $3 \%$ in their protein, total solids, and fat levels were observed and there was also a range of $\mathrm{pH}$ values, which are known to influence the texture of cream cheese and acid-induced gels (Martens, 1972; Becker and Puhan, 1989; Lucey et al., 1998; 


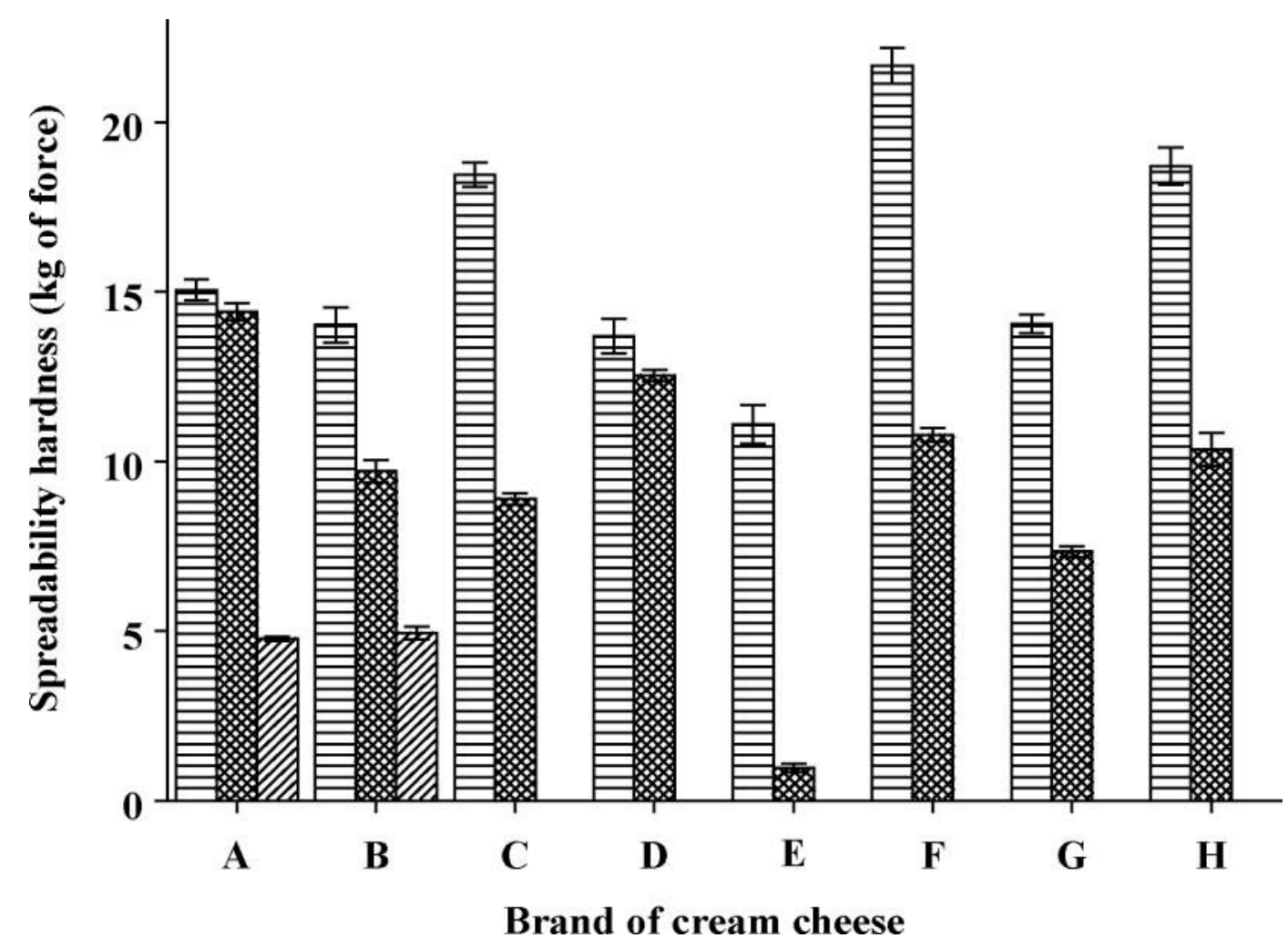

Figure 4. Hardness determined by spreadability test of full-fat (horizontal hatch), Neufchatel (cross hatch), and fat-free (diagonal hatch) cream cheeses obtained from 8 different brands. Values are means of at least 3 replicates and error bars represent standard deviations of the mean.

Tamime and Robinson, 1999; Schulz-Collins and Senge, 2004). Another reason for the differences observed between cream cheeses within the same category probably arise from the use of different processing factors during their manufacture (because these brands were made by different companies). When dealing with commercial samples, it is not possible to know what processing parameters had been used to manufacture the different cream cheeses. Therefore, the exact origin of the differences between cream cheeses from the same category cannot be determined. The type of brand was found to be a significant factor in most of the differences we observed in the rheological, textural, and sensory attributes.

In full-fat and Neufchatel cream cheeses we observed that during the heating cycle, the rate of decrease in $\mathrm{G}^{\prime}$ values was steeper at temperatures below $40^{\circ} \mathrm{C}$ than the rate of decrease at temperatures above $40^{\circ} \mathrm{C}$ (Figure 1 ). When cheeses were heated, the fat embedded in the protein matrix melted at temperatures below $40^{\circ} \mathrm{C}$, which contributed to the steep decrease in $G^{\prime}$ values. This decrease in $G^{\prime}$ was greater for full-fat cream cheeses than for Neufchatel cheeses because of the greater fat content of full-fat cream cheeses. Besides melting of the fat, other changes in cream cheese occurred with increasing temperature because $\mathrm{G}^{\prime}$ values continued to decrease at temperatures above $40^{\circ} \mathrm{C}$ when milk fat was completely liquid. With an increase in temperatures there is an increase in thermal motion of molecules, particles, and strands and there is a faster relaxation of protein-protein bonds (Lucey et al., 2003). Hydrophobic interactions increase with increasing temperature, which causes the casein molecules to contract; as a result, the stiffness of the milk gel network is reduced (Lucey et al., 2003). Some of the weakening of gels with increasing temperature could also be due to the decrease in strength of hydrogen bonds (Bryant and McClements, 1998). The $\mathrm{G}^{\prime}$ values of cream cheese do not decrease to the same extent as rennet-coagulated cheeses over the temperature range 5 to $80^{\circ} \mathrm{C}$. With the exception of full-fat cream cheese from brand $\mathrm{E}$, the $\mathrm{G}^{\prime}$ values of these cheeses remain at $\geq 1,000 \mathrm{~Pa}$ even at $80^{\circ} \mathrm{C}$. This could be because cream cheeses have $\mathrm{pH}$ values that are near the isoelectric point of casein (Table 4). In low $\mathrm{pH}$ cheeses there are a lot of attractive hydrophobic and electrostatic interactions (+/ - charges; Lucey et al., 2003), which help to prevent the structure from exhibiting excessive weakening during heating. 


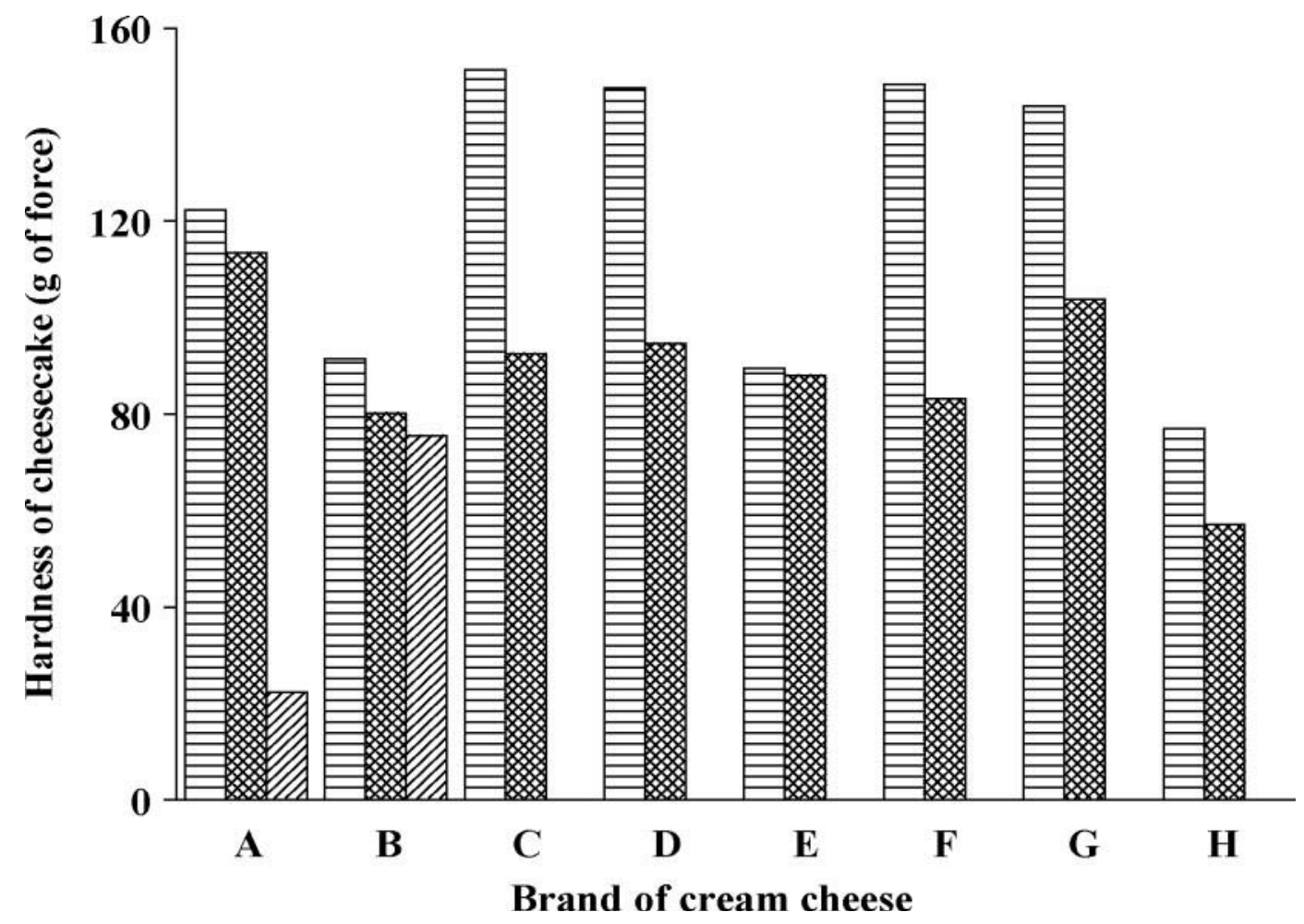

Figure 5. Hardness determined by penetration test of cheesecakes made with full-fat (horizontal hatch), Neufchatel (cross hatch), and fatfree (diagonal hatch) cream cheeses obtained from 8 different brands.

In the absence of fat (i.e., in fat-free cream cheeses), there was still a decrease in $\mathrm{G}^{\prime}$ values during heating from 5 to $80^{\circ} \mathrm{C}$, which could be due to increased hydrophobic interactions and decreased hydrogen bonding. However, the relatively constant rate of decrease in the $\mathrm{G}^{\prime}$ values observed during heating from 5 to $80^{\circ} \mathrm{C}$ indicated that, at temperatures below $40^{\circ} \mathrm{C}$, the structure of fat-free cheeses weakened even in the absence of milk fat.

Fat-free cheeses had greater $\mathrm{G}^{\prime}$ values at high temperatures (from $\sim 40$ to $75^{\circ} \mathrm{C}$ ) compared with full-fat or Neufchatel cheeses, which could be because of their greater protein content (Table 4) or the presence of a greater concentration of other ingredients including stabilizers such as carrageenan (Crane, 1992), in addition to the typical stabilizer already added in full-fat and Neufchatel cheeses (i.e., xanthan, locust bean, or guar gums).

The increase in $\mathrm{G}^{\prime}$ values during the cooling cycle from 80 to $\sim 30^{\circ} \mathrm{C}$ was because of an increase in the number of protein-protein interactions, such as hydrogen bonds, that increase at lower temperatures (Lucey et al., 2003). At temperatures below $30^{\circ} \mathrm{C}$, there was a large rate of increase in $\mathrm{G}^{\prime}$, which could be due to milk fat crystallization (solidification) in this temperature region (Lopez et al., 2002; Lopez et al., 2006). The hysteresis in the $\mathrm{G}^{\prime}$ values between 40 and $5^{\circ} \mathrm{C}$ ob- tained during the heating and cooling cycles could be because that fat needs to be supercooled (i.e., taken to a temperature below its melting point) to crystallize (Wright and Marangoni, 2003). Thus, melting of milk fat during heating and crystallization during cooling occur at different temperatures. It is also likely that structural changes that occurred at high temperatures in the protein matrix could have been irreversible, which was supported by the observation that after the heating and cooling cycles, the $\mathrm{G}^{\prime}$ values at $5^{\circ} \mathrm{C}$ were lower than the initial $\mathrm{G}^{\prime}$ values at $5^{\circ} \mathrm{C}$ before the start of the heating cycle. It appeared that the original structure of cream cheese was not completely recovered after the heating and cooling cycles.

The LT peaks observed in full-fat and Neufchatel cheeses at temperatures below $40^{\circ} \mathrm{C}$ could be due to melting of fat. In cream cheese, the homogenized fat particles are part (active filler) of the protein matrix (Kaláb et al., 1981; Guinee et al., 1993; Sanchez et al., 1996). When fat melts, this phase transition (solid to liquid) may alter the mechanical properties of this matrix. Greater values for the maximum LT were observed in full-fat cream cheeses compared with Neufchatel cheeses probably because of the greater fat content in full-fat cheeses. The absence of an LT peak at temperatures between 5 to $40^{\circ} \mathrm{C}$ in fat-free cream cheeses was further indication that the LT peak in full-fat and Neufchatel 


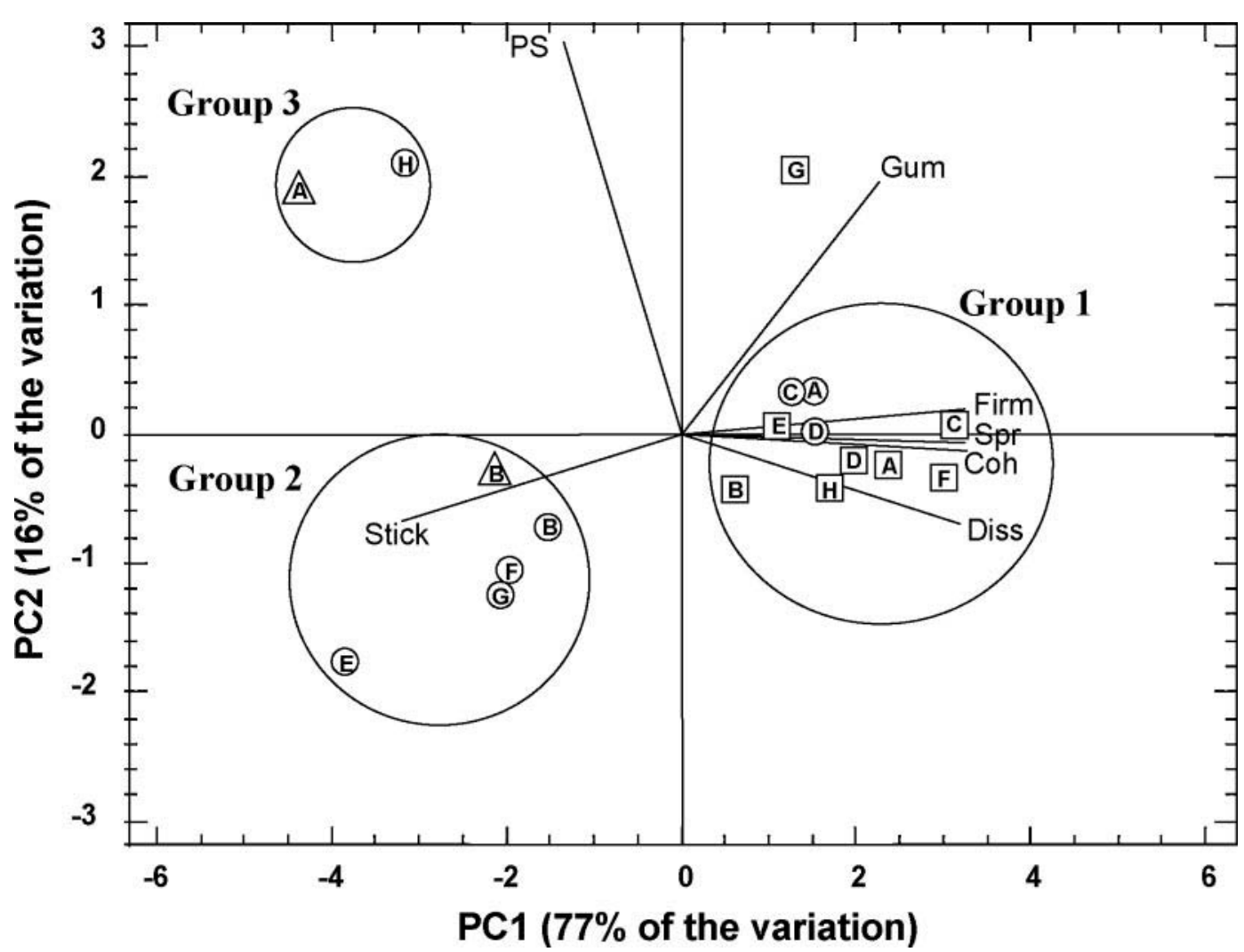

Figure 6. Principal component analysis biplot of sensory parameters used to differentiate full-fat $(\square)$, Neufchatel $(\bigcirc)$, and fat-free $(\Delta)$ cream cheeses. Key for sensory parameters: Firm = firmness; Stick = stickiness; Gum $=$ gumminess; Coh $=$ cohesiveness of mass; Diss $=$ difficulty to dissolve; PS = particle size; $\mathrm{Spr}=$ difficulty to spread. The letter shown inside each symbol is the brand of cream cheese.

cheeses was caused by melting of fat. The second and smaller peak observed at $\sim 60^{\circ} \mathrm{C}$ could be due to the relaxation of some specific protein interactions because, in rennet-coagulated cheeses, a peak is observed in this temperature region (Lucey et al., 2003). The peak at $\sim 60^{\circ} \mathrm{C}$ tended to be slightly greater in Neufchatel cheeses, which could be due to the greater protein concentration of these cheeses compared with full-fat cream cheeses (Table 4). The relatively low LT values (i.e., < 0.40 ) observed for all cream cheese types indicate that, throughout the heating cycle, cream cheese structure remained solid-like (Figure 3). This could be because of the presence of a high number of attractive interactions $(+/-$ electrostatic $)$ in cream cheese. It has previously been observed that low $\mathrm{pH}$ cheeses have low LT values during heating (Lucey et al., 2003; Lee et al., 2005).

Full-fat cream cheeses had significantly $(P<0.0001)$ greater $\mathrm{G}_{8 \mathrm{C}}^{\prime}$ and greater hardness/firmness attributes compared with Neufchatel and fat-free cream cheeses (Figures 1, 3, 4, and 6). This could be due to the greater total solids and fat content in full-fat cream cheeses (Table 4). Homogenization of milk fat results in proteins

Table 7. Pearson correlation coefficients between the instrumental (rheological and textural) parameters and sensory properties

\begin{tabular}{lccc}
\hline & & \multicolumn{2}{c}{ Instrumental texture } \\
\cline { 3 - 4 } Sensory & $\begin{array}{c}\text { Storage modulus } \\
\text { at } 8^{\circ} \mathrm{C}\left(\mathrm{G}_{8 \mathrm{C}}^{\prime}\right)\end{array}$ & $\begin{array}{c}\text { Penetration } \\
\text { hardness }(\mathrm{Hp})\end{array}$ & $\begin{array}{c}\text { Spreadability } \\
\text { hardness }(\mathrm{Hs})\end{array}$ \\
\hline Firmness & $0.79^{* * *}$ & $0.89^{* * *}$ & $0.88^{* * *}$ \\
Stickiness & $-0.69^{* *}$ & $-0.85^{* * *}$ & $-0.83^{* * *}$ \\
Gumminess & - & $0.51^{* *}$ & $0.55^{*}$ \\
Cohesiveness of mass & $0.76^{* * *}$ & $0.85^{* * *}$ & $0.86^{* * *}$ \\
Difficulty to dissolve & $0.79^{* * *}$ & $0.83^{* * *}$ & $0.84^{* * *}$ \\
Difficulty to spread & $0.76^{* * *}$ & $0.85^{* * *}$ & $0.87^{* * *}$ \\
\hline
\end{tabular}

${ }^{*} P<0.05 ;{ }^{* *} P<0.01 ;{ }^{* * *} P<0.001$. 


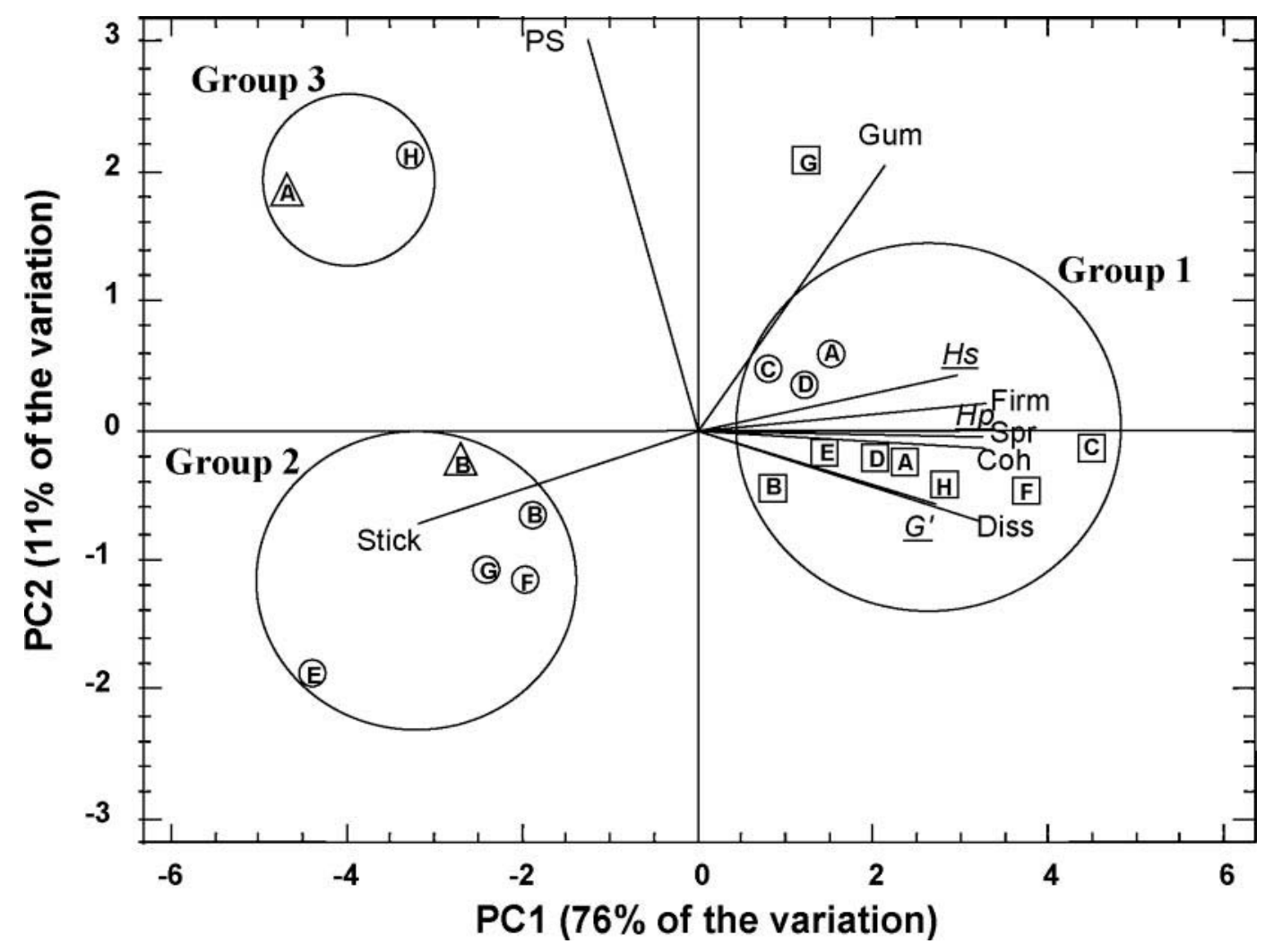

Figure 7. Principal component analysis biplot of sensory and instrumental parameters used to differentiate full-fat ( $\square$ ), Neufchatel ( $\bigcirc)$, and fat-free $(\Delta)$ cream cheeses. Key for sensory parameters: Firm = firmness; Stick = stickiness; Gum = gumminess; Coh = cohesiveness of mass; Diss = difficulty to dissolve; $\mathrm{PS}=$ particle size; $\mathrm{Spr}=$ difficulty to spread. Key for instrumental parameters: $G^{\prime}=\mathrm{G}^{\prime}$ values at $8^{\circ} \mathrm{C} ; \underline{H s}$ $=$ spreadability hardness; $\underline{H p}=$ penetration hardness. The letter shown inside each symbol is the brand of cream cheese.

(mainly caseins) becoming absorbed at the newly created fat globule interface (Tomas et al., 1994; Cho et al., 1999; Sodini et al., 2004). After homogenization the effective protein concentration is greatly increased (Walstra et al., 1999; Schulz-Collins and Senge, 2004) and these new fat particles become incorporated into the acid-induced gel matrix during acidification and act as an active filling material (Lucey et al., 1998; Cho et al., 1999; Lee and Sherbon, 2002). These new fat globules increase the number of interactions present in cream cheese structure. The greater concentration of both homogenized fat and total solids in full-fat cream cheese is probably responsible for this cheese exhibiting a greater level of stiffness compared with Neufchatel and fat-free cheeses (Kealy, 2006), in spite of full-fat cheese having lower protein contents. In contrast to cheeses manufactured from unhomogenized milk, in which fat is an inert filler, lower contents of fat results in cheeses with a greater protein content and thus greater $\mathrm{G}^{\prime}$ values and firmness (Bryant et al., 1995; Ustunol et al., 1995; Guinee and McSweeney, 2003). Greater Hp values from the penetration tests for full-fat cream cheeses compared with Neufchatel cheeses are in agreement with the results of Almena-Aliste and
Kindstedt (2005). Kealy (2006) also found that cream cheeses having greater fat content showed greater firmness and cohesiveness values as determined by sensory analysis. In acid milk gels with increased levels of homogenized fat and total solids greater firmness was also observed (Pereira et al., 2006). In the case of difficulty to spread, previous studies performed on cream cheeses with different fat levels have also indicated that cream cheeses with greater fat contents $(34 \%)$ were less spreadable than those with lower fat contents $(22 \%$; Wendin et al., 2000).

The $\mathrm{G}^{\prime}$ values at low temperatures $\left(<30^{\circ} \mathrm{C}\right)$ and the results of both the instrumental and sensory tests for texture (which were performed at $5^{\circ} \mathrm{C}$ ) were likely influenced by the presence of partly crystalline/solid milk fat. At temperatures $\sim 4$ to $8^{\circ} \mathrm{C}$, the solid fat in cream cheese should contribute to reinforcing the gel structure.

The high positive correlations $(\mathrm{r}>0.94 ; P<0.0001)$ observed between the sensory attributes (firmness, cohesiveness of mass, difficulty to dissolve, and difficulty to spread) and the clustering of these attributes in the biplot of PC1 versus PC2 (Figure 6) could indicate that 
these attributes are describing similar characteristics for these cheeses. All these terms appear to be related to the hardness/firmness of the samples.

The high positive correlations observed between the results obtained from the instrumental tests and the sensory attributes could be explained by the fact that these attributes are related to the strength of the interactions in the samples (Table 7). For this reason, PCA on both sensory and instrumental results (Figure 7) gave a biplot of $\mathrm{PC} 1$ versus $\mathrm{PC} 2$ in which all of these attributes were grouped. Brown et al. (2003) also found high correlations between sensory and rheological methods associated with firmness in young cheeses. The clustering of most full-fat cream cheeses in the lower right quadrant of the biplot of $\mathrm{PC} 1$ versus $\mathrm{PC} 2$ (Figure 7) indicated that at this fat level, cheeses with similar fat content exhibited similar textural and rheological properties despite coming from different brands. Full-fat cream cheese from brand $\mathrm{G}$ was an exception to this because of its high gumminess. Neufchatel cheeses were found in different groups (Figure 7), indicating greater variability in their textural and rheological profiles depending on their brand. This could be because they also showed greater variability in their composition (Table 4). In the case of the fat-free samples, they also fell into 2 different groups because of differences in their particle sizes (Figure 7).

Cream cheeses with greater stickiness were also softer, which was indicated by the high negative correlations between stickiness and the sensory and instrumental measurements associated with hardness (Table 5). This is in agreement with the Dahlquist criterion, which states that stickiness does not occur in hard materials (i.e., $\mathrm{G}^{\prime}$ values $>10^{5} \mathrm{~Pa}$; Dahlquist, 1969). Most full-fat cheeses had $\mathrm{G}^{\prime}$ values $\geq 10^{5} \mathrm{~Pa}$ at $5^{\circ} \mathrm{C}$.

A trend was observed wherein most full-fat cream cheeses gave harder cheesecakes compared with cheesecakes made with Neufchatel cheeses. This trend indicates that there is a correlation between the textural and rheological properties of cream cheese and its application in cheesecakes.

\section{CONCLUSIONS}

Full-fat cream cheeses were more elastic, harder, and more cohesive than Neufchatel or fat-free cheeses, which could be due to the greater total solids and homogenized fat contents of full-fat cheese. In full-fat and Neufchatel cheeses, melting of the fat during heating between 5 and $40^{\circ} \mathrm{C}$ caused a decrease in the $\mathrm{G}^{\prime}$ and a maximum in LT values. The rheological profiles of fat-free cream cheeses exhibited very different rheological and textural properties during the heating/cooling cycles compared with full-fat and Neufchatel cheese, presumably because of the absence of fat, the presence of a greater content of gums/stabilizers, differences in the manufacturing processes, or a combination of these factors. The high correlations observed between instrumental and sensory parameters related to elasticity, firmness, or difficulty to spread indicated that these instrumental tests could be good predictors for cream cheese sensory attributes.

\section{ACKNOWLEDGMENTS}

The authors appreciate the financial support of Dairy Management Inc. (Rosemont, IL) and Wisconsin Milk Marketing Board (Madison, WI). We also wish to thank Alice Ping (Wisconsin Center for Dairy Research) for her help in setting up the sensory panel and Arnoldo López-Hernández (University of Wisconsin-Madison) for statistical advice.

\section{REFERENCES}

Abboud, A. 1998. Technology of producing cheesecakes. American Institute of Baking Research Department Technical Bulletin. $20: 1-6$.

Almena-Aliste, M., and P. S. Kindstedt. 2005. Effect of increasing pH on texture of full and reduced-fat cream cheese. Aust. J. Dairy Technol. 60:225-230.

Becker, T., and Z. Puhan. 1989. Effect of different processes to increase the milk solids non-fat content on the rheological properties of yoghurt. Milchwissenschaft 44:626-629.

Brown, J. A., E. A. Foegeding, C. R. Daubert, M. A. Drake, and M. Gumpertz. 2003. Relationships among rheological and sensorial properties of young cheeses. J. Dairy Sci. 86:3054-3067.

Bryant, A., Z. Ustunol, and J. Steffe. 1995. Texture of Cheddar cheese as influenced by fat reduction. J. Food Sci. 60:1216-1219, 1236.

Bryant, C. M., and D. J. McClements. 1998. Molecular basis of protein functionality with special consideration of cold-set gels derived from heat-denatured whey. Trends Food Sci. Technol. 9:143-151.

Cho, Y. H., J. A. Lucey, and H. Singh. 1999. Rheological properties of acid milk gels as affected by the nature of the fat globule surface material and heat treatment of milk. Int. Dairy J. 9:537-545.

Code of Federal Regulations. 2006a. Food and Drugs: CFR Part 101 Food Labeling. Department of Health and Human Services, Washington, DC.

Code of Federal Regulations. 2006b. Food and Drugs: CFR Part 133 Cheese and Related Cheese Products. Department of Health and Human Services, Washington, DC.

Crane, L. A. 1992. Method of manufacture of a non-fat cream cheese product. Kraft General Foods Inc., assignee. US Pat. No. $5,079,024$.

Dahlquist, C. A. 1969. Tack. Pages 143-151 in Adhesion: Fundamentals and Practice. The Ministry of Technology (UK). Gordon and Breach Science Publishers Inc., New York, NY.

Fox, P. F., T. P. Guinee, T. M. Cogan, and P. L. H. McSweeney. 2000. Fundamentals of Cheese Science. Aspen Publ., Gaithersburg, MD.

Guinee, T. P., and P. L. H. McSweeney. 2003. Significance of milk fat in cheese. Pages 377-440 in Advanced Dairy Chemistry. Vol. 2. 3rd ed. P. F. Fox and P. L. H. McSweeney, ed. Kluwer Academic/ Plenum, New York, NY.

Guinee, T. P., P. D. Pudja, and N. Y. Farkye. 1993. Fresh acid-curd cheese varieties. Pages 363-419 in Cheese: Chemistry, Physics and Microbiology. Vol. 1. 2nd ed. P. F. Fox, ed. Chapman \& Hall, London, UK. 
IDF. 1982. Determination of total solids content of cheese and processed cheese. 4A:1982. International Dairy Federation, Brussels, Belgium.

IDF. 1986. Determination of nitrogen content (Kjeldahl method) and calculation of crude protein content. 20A:1986. International Dairy Federation, Brussels, Belgium.

IDFA. 2007. Dairy Facts, 2007 ed. International Dairy Foods Association, Washington, DC.

Kaláb, M., A. G. Sargant, and D. A. Froehlich. 1981. Electron microscopy and sensory evaluation of commercial cream cheese. Scan. Electron Microsc. 3:473-482, 514

Kealy, T. 2006. Application of liquid and solid rheological technologies to the textural characterization of semi-solid foods. Food Res. Int. $39: 265-276$.

Lee, M.-R., M. E. Johnson, and J. A. Lucey. 2005. Impact of modifications in acid development on the insoluble calcium content and rheological properties of Cheddar cheese. J. Dairy Sci. 88:3798-3809.

Lee, S. J., and J. W. Sherbon. 2002. Chemical changes in bovine milk fat globule membrane caused by heat treatment and homogenization of whole milk. J. Dairy Res. 69:555-567.

Lopez, C., C. Bourgaux, P. Lesieur, S. Bernadou, G. Keller, and M. Ollivon. 2002. Thermal and structural behavior of milk fat: Influence of cooling rate and droplet size on cream crystallization. J. Colloid Interface Sci. 254:64-78.

Lopez, C., V. Briard-Bion, B. Camier, and J.-Y. Gassi. 2006. Milk fat thermal properties and solid fat content in Emmental cheese: A differential scanning calorimetry study. J. Dairy Sci. 89:28942910.

Lucey, J. A. 2002. Acid and acid/heat coagulated cheese. Pages 350356 in Encyclopedia of Dairy Sciences. H. Roginski, J. W. Fuquay and P. F. Fox, ed. Academic Press, London, UK.

Lucey, J. A., M. E. Johnson, and D. S. Horne. 2003. Perspectives on the basis of the rheology and texture properties of cheese. J. Dairy Sci. 86:2725-2743.

Lucey, J. A., P. A. Munro, and H. Singh. 1998. Rheological properties and microstructure of acid milk gels as affected by fat content and heat treatment. J. Food Sci. 63:660-664.

Marshall, R. T. 1992. Standard Methods for the Examination of Dairy Products. 16th ed. American Public Health Association, Washington, DC.

Martens, R. 1972. Influence de quelques facteurs sur la consistance et le goût du yoghourt brassé. Rev. Agric. 3:461-480.

Meilgaard, M., G. V. Civille, and B. T. Carr. 1999. Sensory evaluation techniques. 3rd ed. CRC Press, Boca Raton, FL.

Pereira, R., L. Matia-Merino, V. Jones, and H. Singh. 2006. Influence of fat on the perceived texture of set acid milk gels: A sensory perspective. Food Hydrocoll. 20:305-313.
Phadungath, C. 2003. A study of structure development in cream cheese and the impact of processing conditions on cheese texture, and sensory properties. MS thesis. Univ. of Wisconsin, Madison.

Sanchez, C., J.-L. Beauregard, M. Bride, W. Buchheim, and J. Hardy. 1996. Rheological and microstructural characterization of double cream cheese. Nahrung 40:108-116.

Sanchez, C., J.-L. Beauregard, M.-H. Chassagne, J. J. Bimbenet, and J. Hardy. 1994a. Rheological and textural behaviour of double cream cheese. Part I: Effect of curd homogenization. J. Food Eng. 23:579-594.

Sanchez, C., J.-L. Beauregard, M.-H. Chassagne, A. Duquenoy, and J. Hardy. 1994b. Rheological and textural behaviour of double cream cheese. Part II: Effect of curd cooling rate. J. Food Eng. 23:595-608.

SAS Institute. 2003. SAS User's Guide: Statistics. Version 9.1 ed. SAS Inst. Inc., Cary, NC

Schulz-Collins, D., and B. Senge. 2004. Acid and acid/rennet-curd cheeses. Part A: Quark, cream cheese and related varieties. Pages 301-328 in Cheese Chemistry, Physics and Microbiology, Vol. 2, Major Cheese Groups. 3rd ed. Elsevier Science \& Technology, London, UK.

Sodini, I., F. Remeuf, S. Haddad, and G. Corrieu. 2004. The relative effect of milk base, starter, and process on yogurt texture: A review. Crit. Rev. Food Sci. Nutr. 44:113-137.

Swenson, B. J., W. L. Wendorff, and R. C. Lindsay. 2000. Effects of ingredients on the functionality of fat-free process cheese spreads. J. Food Sci. 65:822-825.

Tamime, A. Y., and R. K. Robinson. 1999. Yoghurt: Science and Technology. 2nd ed. Woodhead Publishing Limited, Cambridge, UK.

Tomas, A., D. Paquet, J.-L. Courthaudon, and D. Lorient. 1994. Effect of fat and protein contents on droplet size and surface protein coverage in dairy emulsions. J. Dairy Sci. 77:413-417.

Ustunol, Z., K. Kawachi, and J. Steffe. 1995. Rheological properties of Cheddar cheese as influenced by fat reduction and ripening time. J. Food Sci. 60:1208-1210.

Walstra, P., T. J. Geurts, A. Noomen, A. Jellema, and M. A. J. S. van Boekel. 1999. Homogenization. Pages 245-264 in Dairy Technology: Principles of Milk Properties and Processes. Marcel Dekker, New York, NY.

Wendin, K., M. Langton, L. Caous, and G. Hall. 2000. Dynamic analyses of sensory and microstructural properties of cream cheese. Food Chem. 71:363-378.

Wright, A. J., and A. G. Marangoni. 2003. Crystallization and rheological properties of milk fat. Pages 245-291 in Advanced Dairy Chemistry. Vol. 2. 3rd ed. P. F. Fox and P. L. H. McSweeney, ed. Kluwer Academic/Plenum, New York, NY. 